\title{
Synthesis, structure and biological activity of nickel(II) complexes of 5-methyl 2-furfural thiosemicarbazone
}

\author{
El Mostapha Jouad ${ }^{\mathrm{a}}$, Gérald Larcher ${ }^{\mathrm{b}}$, Magali Allain ${ }^{\mathrm{c}}$, Amédée Riou ${ }^{\mathrm{c}}$, Gilles M. Bouet ${ }^{\mathrm{a}, *}$, \\ Mustayeen A. Khan ${ }^{\mathrm{a}}$, Xuan Do Thanh ${ }^{\mathrm{d}}$ \\ ${ }^{a}$ Chimie de Coordination, Faculté de Pharmacie, Université d'Angers, 16 Boulevard Daviers, F-49045 Angers Cedex 01, France \\ ${ }^{\mathrm{b}}$ Groupe d'Étude des Interactions Hôte-Parasite, Laboratoire de Parasitologie-Mycologie, Centre Hospitalier Universitaire, 4, rue Larrey, \\ F-49033 Angers, France \\ ${ }^{\mathrm{c}}$ IMMO, UMR CNRS 6501, Faculté des Sciences, 2 boulevard Lavoisier, 49045 Angers Cedex, France \\ ${ }^{\mathrm{d}}$ Laboratoire de Pharmacologie-Toxicologie, Facultés de Médecine et Pharmacie, Université d'Angers, 16 Boulevard Daviers, 49100 Angers, France
}

Received 29 November 2000; received in revised form 4 April 2001; accepted 4 April 2001

\begin{abstract}
5-Methyl 2-furfuraldehyde thiosemicarbazone (M5HFTSC) with nickel(II) leads to three types of complexes: [Ni(M5HFTSC) ${ }_{2} \mathrm{X}_{2}$ ], $\left[\mathrm{Ni}(\mathrm{M} 5 \mathrm{FTSC})_{2}\right]$ and $\left[\mathrm{Ni}(\mathrm{M} 5 \mathrm{FTSC})_{2}\right] \cdot 2 \mathrm{DMF}$. In the first type the ligand remains in thione form, while in the two other, the anionic thiolato form is involved. The species [Ni(M5HFTSC) $)_{2} \mathrm{X}_{2}$ ] has been characterized spectroscopically. The structures of [Ni(M5FTSC) $)_{2}$ $2 \mathrm{DMF}$ and $\left[\mathrm{Ni}(\mathrm{M} 5 \mathrm{FTSC})_{2}\right]$ have been solved using X-ray diffraction. Biological studies of $\left[\mathrm{Ni}\left(\mathrm{M}_{5} \mathrm{HFTSC}_{2} \mathrm{Cl}_{2}\right]\right.$ have been carried out in vitro for antifungal activity on human pathogenic fungi, Aspergillus fumigatus and Candida albicans, and in vivo for toxicity on mice. The results are compared to those of the ligand, the metal salt and a similar copper complex $\left[\mathrm{Cu}\left(\mathrm{M}_{5 \mathrm{HFTSC}} \mathrm{Cl}_{2}\right]\right.$. CC 2001 Elsevier Science B.V. All rights reserved.
\end{abstract}

Keywords: Ni(II) complexes; Thiosemicarbazone complexes; Crystal structures; Spectroscopic studies; Biological activity

\section{Introduction}

The heterocyclic thiosemicarbazones and their metal complexes are among the most widely studied compounds for their potential therapeutic uses, such as antitumoral [1-5], fungicidal [6,7], bactericidal [8] or antiviral [3] activity.

We have previously described the complexes formed between various furan oximes [9] and semicarbazones with $3 d$ metal dihalides [10]. The cytotoxic activity of some of the copper complexes has been characterized in our laboratory [11] as well as similar compounds [12,13].

We report here the synthesis and the characterization of complexes obtained by reaction of M5HFTSC with chlorides and bromides of $\mathrm{Ni}(\mathrm{II})$, where M5HFTSC is 5methyl 2-furfuralehyde thiosemicarbazone. The crystal structures of the two complexes obtained, [Ni(M5FTSC $\left.)_{2}\right]$ and $\left[\mathrm{Ni}(\mathrm{M} 5 \mathrm{FTSC})_{2}\right] \cdot 2 \mathrm{DMF}$ are discussed. Due to few

\footnotetext{
*Corresponding author. Tel.: +33-2-4122-6600; fax: +33-2-41486733.

E-mail address: gilles.bouet@univ-angers.fr (G.M. Bouet).
}

studies concerning the biological activity of nickel complexes of thiosemicarbazones [14,15], the biological properties of $\left[\mathrm{Ni}(\mathrm{M} 5 \mathrm{HFTSC})_{2} \mathrm{Cl}_{2}\right]$ were also studied and compared to $\left[\mathrm{Cu}(\mathrm{M} 5 \mathrm{HFTSC}) \mathrm{Cl}_{2}\right]$ which was described earlier [16]. The biological properties were tested in vivo on mice and in vitro on human pathogenic fungi, Aspergillus fumigatus and Candida albicans.

\section{Experimental}

\subsection{Reactants}

All reactants and solvents were of analytical grade. Thiosemicarbazide, 5-methylfurfural and nickel salts were purchased from Merck, Aldrich and Prolabo, respectively, and used without further treatment.

\subsection{Measurements}

Elemental analyses were carried out by the 'Service Central d'Analyses' (CNRS, Vernaison, France). Melting 
points were determined with a digital melting point apparatus using capillary technique. Conductance values were obtained with a Tacussel CD6NG conductometer at $25^{\circ} \mathrm{C}(298 \mathrm{~K})$ from $10^{-3} \mathrm{M}$ solutions of complexes in absolute EtOH. The solvent had a conductance of $10^{-8} \mathrm{~S}$.

The IR spectra were recorded with a Shimadzu FTIR$8010 \mathrm{M}$ spectrometer between 400 and $4600 \mathrm{~cm}^{-1}(\mathrm{KBr}$ disks) and with a Nicolet FTIR 20F in the range 50-400 $\mathrm{cm}^{-1}$ using polyethylene disks (Institut des Matériaux de Nantes, France). Electronic spectra were recorded with a Perkin-Elmer Lambda 19 spectrometer in ethanolic solutions $\left(10^{-3} \mathrm{M}\right)$. The ${ }^{1} \mathrm{H}$ NMR spectra were recorded on a Bruker Advance DRX 500 in DMSO- $d_{6}$ operating at 500 $\mathrm{MHz}$. The chemical shifts, $\delta$, are given in parts per million (relative to TMS) and coupling constants in Hertz.

\subsection{Preparation of ligand}

The 5-methyl 2-furfuraldehyde thiosemicarbazone was obtained as previously described [2] from 5-methyl furfural and thiosemicarbazide (1:1 molar ratio) in absolute ethanol in the presence of pure acetic acid. The mixture was refluxed for $1 \mathrm{~h}$ and then cooled, filtered and recrystallized from a mixture of ethanol $(75 \%)$ and water. Yellow microcrystalline products were obtained. [Analysis results for $\mathrm{C}_{7} \mathrm{H}_{9} \mathrm{~N}_{3} \mathrm{OS}$. Found: C, 45.71; $\mathrm{H}, 4.95 ; \mathrm{N}, 22.59$. Calculated: C, $45.89 ; \mathrm{H}, 4.95 ; \mathrm{N}, 22.93 \%$. M.P. $=165^{\circ} \mathrm{C}$ and $\lambda=0.82 \mathrm{~S} \mathrm{~cm}^{2} \mathrm{~mol}^{-1}$ ].

\subsection{Preparation of complexes}

\subsection{1. [Ni(M5HFTSC $)_{2} \mathrm{Cl}_{2}$ ]}

The hexahydrated salt of nickel, $\mathrm{NiCl}_{2} \cdot 6 \mathrm{H}_{2} \mathrm{O}\left(5 \times 10^{-3}\right.$ mol, $0.92 \mathrm{~g}$ ), was dissolved in $n-\mathrm{BuOH}$. This solution was heated until the solvent refluxed and then $10 \mathrm{ml}$ of an equimolar $n$-BuOH solution of M5HFTSC was added slowly while stirring. The mixture was refluxed for $24 \mathrm{~h}$ and a green solid was removed by filtration, washed with $\mathrm{MeOH}$ and finally dried in vacuum over silica gel. [Analysis results for $\mathrm{C}_{14} \mathrm{H}_{18} \mathrm{C}_{12} \mathrm{NiN}_{6} \mathrm{O}_{2} \mathrm{~S}_{2}$. Found: C, 33.6; $\mathrm{H}, 3.58 ; \mathrm{Cl}, 14.83 ; \mathrm{Ni}, 11.06$. Calculated: C, 33.90; $\mathrm{H}, 3.66 ; \mathrm{Cl}, 14.29 ; \mathrm{Ni}, 11.83 \%$. M.P. (decomposition) $=$ $222^{\circ} \mathrm{C}$ and $\lambda=31 \mathrm{~S} \mathrm{~cm}^{2} \mathrm{~mol}^{-1}$ ].

\subsection{2. $\left[\mathrm{Ni}(\mathrm{M} 5 \mathrm{FTSC})_{2}\right]$}

When $[\mathrm{Ni} \text { (M5HFTSC })_{2} \mathrm{Cl}_{2}$ ] was dissolved in a mixture of $20 \mathrm{ml}$ of $\mathrm{EtOH}$ and two drops of hydrochloric acid, dark-green crystals of formula [Ni(M5FTSC $)_{2}$ ] were isolated.

\subsection{3. [Ni(M5HFTSC $\left.)_{2} \mathrm{Br}_{2}\right]$}

It was obtained as a green solid in the same way as the chloro complex, but in EtOH solution and refluxing for only $5 \mathrm{~h}$. [Analysis results for $\mathrm{C}_{14} \mathrm{H}_{18} \mathrm{Br}_{2} \mathrm{NiN}_{6} \mathrm{O}_{2} \mathrm{~S}_{2}$. Found: C, 28.89; H, 3.17; Br, 27.32; Ni, 10.24. Calculated:
C, 28.75; H, 3.10; $\mathrm{Br}, 27.32 ; \mathrm{Ni}, 10.03 \%$. M.P. (decomposition) $=236^{\circ} \mathrm{C}$ and $\lambda=39 \mathrm{~S} \mathrm{~cm}^{2} \mathrm{~mol}^{-1}$ ].

\subsection{4. $\left[\mathrm{Ni}(\mathrm{MSFTSC})_{2}\right] \cdot 2 \mathrm{DMF}$}

When [Ni(M5HFTSC) ${ }_{2} \mathrm{Br}_{2}$ ] was dissolved in dimethylformamide (DMF), a dark-green crystalline product of formula $\left[\mathrm{Ni}(\mathrm{M} 5 \mathrm{FTSC})_{2}\right] \cdot 2 \mathrm{DMF}$ was isolated after several days.

\subsection{Crystal data collection and processing}

Crystals of $\left[\mathrm{Ni}(\mathrm{M} 5 \mathrm{FTSC})_{2}\right] \cdot 2 \mathrm{DMF}$ are triclinic with space group $P-1$, while those of $\left[\mathrm{Ni}(\mathrm{M} 5 \mathrm{FTSC})_{2}\right]$ are trigonal with space group $R-3$.

The crystal and instrumental parameters used in the unit-cell determination and data collection for both compounds are summarized in Table 1. X-ray diffraction data were collected at $293 \mathrm{~K}$ on an Enraf Nonius MACH3 four-circles diffractometer $\left(\lambda_{\mathrm{Mo} \mathrm{K} \alpha}=0.71073 \AA\right.$ ) equipped with a graphite monochromator (IMMO, UMR, CNRS, 6501 Angers). The structures were solved by direct methods (SIR) using MolEN package programs [17] and F was refined by the full-matrix least-squares techniques.

For $\left[\mathrm{Ni}(\mathrm{M} 5 \mathrm{FTSC})_{2}\right] \cdot 2 \mathrm{DMF}$ all non-hydrogen atoms were refined anisotropically. Some hydrogen atoms were located by a Fourier difference synthesis and the missing atoms were calculated from the HYDRO program [17].

In the case of $\left[\mathrm{Ni}(\mathrm{M} 5 \mathrm{FTSC})_{2}\right]$, the small size of crystal of the complex did not allow us to obtain enough data to specify the hydrogen atoms coordinates and non hydrogen atoms were refined isotropically and the DIFABS program [17] was used for absorption corrections.

\subsection{Biological data}

\subsubsection{Materials and methods}

The metal salt, the ligand and its complexes with copper $\left[\mathrm{Cu}\right.$ (M5HFTSC) $\left.\mathrm{Cl}_{2}\right]$ and with nickel [Ni(M5HFTSC) ${ }_{2} \mathrm{Cl}_{2}$ ] were stored dry at room temperature and dissolved in dimethyl sulfoxide (DMSO) just before their use.

\subsubsection{Antifungal tests}

The broth microdilution test was performed by following the guidelines of the approved reference method for yeasts (NCCLS document M27-A) [18]. An antifungal susceptibility test was performed with Candida albicans (ATCC 663.90) and Aspergillus fumigatus (CBS 113.26) using RPMI-1640 medium (Sigma) with $2 \mathrm{mM} \mathrm{L-}$ glutamine, buffered at $\mathrm{pH} 7.0$ with $0.165 \mathrm{M}$ morpholine propane-sulfonic acid (MOPS) and then sterilized by filtration. The fungal suspensions were prepared in RPMI1640 culture medium and spectrophotometrically adjusted at $630 \mathrm{~nm}$ to give final inocula concentrations of about $5 \times 10^{3}$ to $2.5 \times 10^{4}$ cells ml ${ }^{-1}$. The broth microdilution tests were performed using sterile 96-well flat-shaped microtitre plates. Each well was inoculated with $195 \mu$ l of 
Table 1

Crystallographic data for $\left[\mathrm{Ni}(\mathrm{M} 5 \mathrm{FTSC})_{2}\right] \cdot 2 \mathrm{DMF}$ and $\left[\mathrm{Ni}(\mathrm{M} 5 \mathrm{FTSC})_{2}\right]$

\begin{tabular}{|c|c|c|}
\hline & \multicolumn{2}{|l|}{ Compound } \\
\hline & {$\left[\mathrm{Ni}(\mathrm{M} 5 \mathrm{FTSC})_{2}\right] \cdot 2 \mathrm{DMF}$} & {$\left[\mathrm{Ni}(\mathrm{M} 5 \mathrm{FTSC})_{2}\right]$} \\
\hline Formula & $\mathrm{C}_{20} \mathrm{H}_{30} \mathrm{~N}_{8} \mathrm{NiO}_{4} \mathrm{~S}_{2}$ & $\mathrm{C}_{14} \mathrm{H}_{16} \mathrm{~N}_{6} \mathrm{Ni} \mathrm{O}_{2} \mathrm{~S}_{2}$ \\
\hline Molecular weight & 569.35 & 423.14 \\
\hline Crystal system & Triclinic & Trigonal \\
\hline Space group & $P-1$ & $R-3$ \\
\hline$a / \AA$ & $7.828(1)$ & $14.60(1)$ \\
\hline$b / \AA$ & $8.4779(6)$ & $14.60(1)$ \\
\hline$c / \AA$ & $10.610(1)$ & $21.90(1)$ \\
\hline$\alpha /^{\circ}$ & $72.950(6)$ & 90 \\
\hline$\beta /^{\circ}$ & $79.19(1)$ & 90 \\
\hline$\gamma /{ }^{\circ}$ & $82.243(9)$ & 120 \\
\hline$V / \AA^{3}$ & $658.8(1)$ & $4047(9)$ \\
\hline Z & 1 & 9 \\
\hline Color & Dark-green & Dark-green \\
\hline Crystal size (mm) & $0.29 \times 0.29 \times 0.11$ & $0.14 \times 0.14 \times 0.09$ \\
\hline$D_{\mathrm{c}} / \mathrm{g} \mathrm{cm}^{-3}$ & 1.43 & 1.47 \\
\hline$F(000)$ & 298 & 1836 \\
\hline$\mu\left(\mathrm{mm}^{-1}\right)$ & 0.936 & 1.326 \\
\hline Scan mode & $\omega / 2 \theta$ & $\omega / 2 \theta$ \\
\hline$h k l$ limits & $-9.9 /-10.10 /-13.0$ & $0.13 /-11.0 /-19.19$ \\
\hline$\theta_{\min }, \theta_{\max }$ & $2.5,25.97$ & $2.5,18.79$ \\
\hline Number of data measured & 2730 & 809 \\
\hline Number of data with $I>3 \sigma(I)$ & 1873 & 252 \\
\hline Weighting scheme & $4 F_{\mathrm{o}}^{2} /\left(\left(\sigma\left(F_{\mathrm{o}}^{2}\right)\right)^{2}+0.0064 F_{\mathrm{o}}^{4}\right)$ & $4 F_{\mathrm{o}}^{2} /\left(\left(\sigma\left(F_{\mathrm{o}}^{2}\right)\right)^{2}+0.0064 F_{\mathrm{o}}^{4}\right)$ \\
\hline Number of variables & 176 & 50 \\
\hline$R$ & 0.037 & 0.056 \\
\hline$R_{\mathrm{w}}$ & 0.058 & 0.066 \\
\hline
\end{tabular}

the corresponding fungal working suspension. Serial twofold drug dilutions were made in DMSO, 40 times the strength of the final drug concentration $\left(0.75-10 \mathrm{mg} \mathrm{ml}^{-1}\right)$ and were dispensed in triplicate into the wells of three rows at a volume of $5 \mu \mathrm{l}$. Final concentrations for the drugs were from 1.95 to $250 \mathrm{mg} \mathrm{ml}^{-1}$. The growth control wells contained $195 \mu \mathrm{l}$ of fungal working suspension and 5 $\mu l$ of drug-free DMSO. The positive control was made with amphotericin B. The microplates were incubated at $37^{\circ} \mathrm{C}$ for $48 \mathrm{~h}$ (C. albicans) and $72 \mathrm{~h} \mathrm{(A.} \mathrm{fumigatus)} \mathrm{and}$ spectrophotometric readings of each well were performed at $630 \mathrm{~nm}$ with a Dynatech Laboratories $\mathrm{MRX}_{\mathrm{TC}}$ automatic plate reader. The spectrophotometric MIC (minimum inhibitory concentration) endpoint was calculated from the turbidimetric data as the lowest drug concentration giving rise to an inhibition of growth equal to or greater than $80 \%$ of that of the drug-free control $\left(\mathrm{MIC}_{80}\right)$.

\subsubsection{Toxicity tests}

Male Swiss mice from Debré (France) weighing from 20 to $25 \mathrm{~g}$ were used because of their regular weight gain and the absence of oestral cycle with changes in sexual hormonal status, which could lead to some errors in in vivo experiments.

Animals have free access to both water and standard diet containing $0.8 \% \mathrm{Ca}, 0.7 \% \mathrm{P}$ and $3 \mathrm{IU} \mathrm{g}^{-1}$ vitamin $\mathrm{D}$. They were placed at room temperature $\left(20 \pm 2{ }^{\circ} \mathrm{C}\right)$ and exposed to a 12-h light/dark cycle. After intraperitoneal injection with various doses of studied species, the animals were kept under the same conditions and were kept under observation for 7 days.

\section{Results and discussion}

\subsection{X-ray crystallography}

For comparison, the bond distances and angles of both crystals are shown in Table 2. Fig. 1 shows a view of the molecule of $\left[\mathrm{Ni}(\mathrm{M} 5 \mathrm{FTSC})_{2}\right] \cdot 2 \mathrm{DMF}$, with numbering scheme.

\subsubsection{Crystal structure of $\left[\mathrm{Ni}\left(\mathrm{MSFTSC}_{2}\right] \cdot 2 \mathrm{DMF}\right.$}

The centrosymmetric structure consists of the neutral molecules Ni(M5FTSC) $)_{2}$ with two molecules of dimethylformamide, and the metal at the center of symmetry. The coordination results in a square planar configuration, which involves the thiolato sulfur atoms and the imine nitrogen atom $\mathrm{N} 3$ of the two ligands in trans configuration.

In the complex, the monodeprotonated bidentate ligand shows a cis configuration for the donor nitrogen $\mathrm{N} 3$ and sulfur $\mathrm{S}$ atoms. In the free ligand, however, these centers present a trans-configuration, indicating that the complexation is obtained after a $180^{\circ}$ rotation around the C1-N2 bond [16].

The deprotonation of the ligand on the level of $\mathrm{N} 2$ 
Table 2

Bond lengths $(\AA)$ and angles $\left({ }^{\circ}\right)$ for $\left[\mathrm{Ni}(\mathrm{M} 5 \mathrm{FTSC})_{2}\right] \cdot 2 \mathrm{DMF}$ and $\left[\mathrm{Ni}(\mathrm{M} 5 \mathrm{FTSC})_{2}\right]$

\begin{tabular}{|c|c|c|}
\hline & {$\left[\mathrm{Ni}(\mathrm{M} 5 \mathrm{FTSC})_{2}\right] \cdot 2 \mathrm{DMF}$} & {$\left[\mathrm{Ni}(\mathrm{M} 5 \mathrm{FTSC})_{2}\right]$} \\
\hline \multicolumn{3}{|l|}{ Bond lengths } \\
\hline $\mathrm{Ni}-\mathrm{S}$ & $2.162(1)$ & $2.164(5)$ \\
\hline $\mathrm{Ni}-\mathrm{N} 3$ & $1.912(2)$ & $1.88(2)$ \\
\hline $\mathrm{S}-\mathrm{C} 1$ & $1.734(3)$ & $1.72(2)$ \\
\hline $\mathrm{O} 1-\mathrm{C} 3$ & $1.375(4)$ & $1.39(2)$ \\
\hline $\mathrm{O} 1-\mathrm{C} 6$ & $1.355(4)$ & $1.38(3)$ \\
\hline $\mathrm{O} 2-\mathrm{C} 8$ & $1.229(4)$ & \\
\hline $\mathrm{N} 1-\mathrm{C} 1$ & $1.334(4)$ & $1.39(2)$ \\
\hline $\mathrm{N} 2-\mathrm{N} 3$ & $1.397(3)$ & $1.42(2)$ \\
\hline $\mathrm{N} 2-\mathrm{C} 1$ & $1.307(4)$ & $1.27(3)$ \\
\hline $\mathrm{N} 3-\mathrm{C} 2$ & $1.297(4)$ & $1.31(3)$ \\
\hline $\mathrm{C} 2-\mathrm{C} 3$ & $1.422(4)$ & $1.45(3)$ \\
\hline $\mathrm{C} 3-\mathrm{C} 4$ & $1.360(4)$ & $1.29(3)$ \\
\hline $\mathrm{C} 4-\mathrm{C} 5$ & $1.417(5)$ & $1.36(3)$ \\
\hline C5-C6 & $1.333(5)$ & $1.36(3)$ \\
\hline C6-C7 & $1.496(5)$ & $1.45(3)$ \\
\hline $\mathrm{C} 8-\mathrm{N} 4$ & $1.307(5)$ & \\
\hline C9-N4 & $1.446(5)$ & \\
\hline C10-N4 & $1.425(6)$ & \\
\hline \multicolumn{3}{|l|}{ Bond angles } \\
\hline $\mathrm{S}-\mathrm{Ni}-\mathrm{N} 3$ & $85.15(8)$ & $93.9(4)$ \\
\hline $\mathrm{Ni}-\mathrm{S}-\mathrm{C} 1$ & $96.5(1)$ & $95.0(6)$ \\
\hline $\mathrm{C} 3-\mathrm{O} 1-\mathrm{C} 6$ & $107.0(2)$ & 109(1) \\
\hline $\mathrm{N} 3-\mathrm{N} 2-\mathrm{C} 1$ & $111.8(2)$ & $109(1)$ \\
\hline $\mathrm{Ni}-\mathrm{N} 3-\mathrm{N} 2$ & $120.9(2)$ & $122(1)$ \\
\hline $\mathrm{Ni}-\mathrm{N} 3-\mathrm{C} 2$ & $125.0(2)$ & $125(1)$ \\
\hline $\mathrm{N} 2-\mathrm{N} 3-\mathrm{C} 2$ & $114.1(2)$ & 111(1) \\
\hline $\mathrm{S}-\mathrm{C} 1-\mathrm{N} 1$ & $117.2(2)$ & $116(1)$ \\
\hline $\mathrm{S}-\mathrm{C} 1-\mathrm{N} 2$ & $122.5(2)$ & $127(1)$ \\
\hline $\mathrm{N} 1-\mathrm{C} 1-\mathrm{N} 2$ & $120.3(2)$ & $116(1)$ \\
\hline $\mathrm{N} 3-\mathrm{C} 2-\mathrm{C} 3$ & $128.8(3)$ & $126(1)$ \\
\hline $\mathrm{O} 1-\mathrm{C} 3-\mathrm{C} 2$ & $113.4(3)$ & 111(1) \\
\hline $\mathrm{O} 1-\mathrm{C} 3-\mathrm{C} 4$ & $109.2(3)$ & $105(1)$ \\
\hline $\mathrm{C} 2-\mathrm{C} 3-\mathrm{C} 4$ & $137.4(3)$ & $142(1)$ \\
\hline $\mathrm{C} 3-\mathrm{C} 4-\mathrm{C} 5$ & 106.1(3) & 111(1) \\
\hline $\mathrm{C} 4-\mathrm{C} 5-\mathrm{C} 6$ & $107.5(3)$ & $108(2)$ \\
\hline $\mathrm{O} 1-\mathrm{C} 6-\mathrm{C} 5$ & $110.2(3)$ & 104(1) \\
\hline $\mathrm{O} 1-\mathrm{C} 6-\mathrm{C} 7$ & $116.5(3)$ & $120(1)$ \\
\hline C5-C6-C7 & $133.2(3)$ & $135(2)$ \\
\hline $\mathrm{O} 2-\mathrm{C} 8-\mathrm{N} 4$ & $126.8(4)$ & \\
\hline C8-N4-C9 & $121.4(3)$ & \\
\hline C8-N4-C10 & $121.3(3)$ & \\
\hline C9-N4-C10 & $117.2(3)$ & \\
\hline
\end{tabular}

causes a negative charge delocalized over the thiosemicarbazone moiety. This is explained by the difference noted on the level of the bond distances in the deprotonated ligand of nickel complex which is for $\mathrm{S} 1-\mathrm{C} 1=1.734(3) \AA$ (thiolato form); $\mathrm{C} 1-\mathrm{N} 2=1.307(4) \AA$ and $\mathrm{C} 2-\mathrm{N} 3=$ 1.297(4) $\AA$, and the bond distances in the case of nondeprotonated free ligand, for $\mathrm{S} 1-\mathrm{C} 1=1.684(1) \AA$ (thione form); $\mathrm{C} 1-\mathrm{N} 2=1.341(2) \AA$ and $\mathrm{C} 2-\mathrm{N} 3=1.282(2) \AA[16]$.

The metal and the thiosemicarbazone moiety of the two ligands are in the same plane, while the furanic ring is slightly out of the plane, with an angle of $7.13(1)^{\circ}$. The bond distance of $\mathrm{Ni}-\mathrm{S}=2.162(1) \AA$ is compared to $\mathrm{Ni}-$ $\mathrm{S}=2.134(2) \AA$ [19] and 2.140 (2) $\AA$ [20], which are typical values for square planar nickel species. The calcu- lation distance $\mathrm{Ni}-\mathrm{N}=1.912(2) \AA$ is within the range found in the literature, e.g. $\mathrm{Ni}-\mathrm{N}=1.857(5) \AA$ [21] and $\mathrm{Ni}-\mathrm{N}=1.854(5) \AA$ [20].

The dimethylformamide molecules lie in the cavities between the complexes (Fig. 2) and they control the packing by hydrogen bonds between the nitrogen of the amino group $\mathrm{N} 1$ and the dimethylformamide oxygen atom $\mathrm{N} 1-\mathrm{H} 02 \ldots \mathrm{O} 2=2.35(4) \AA$ and $\mathrm{N} 1-\mathrm{H} 01 \ldots \mathrm{O} 2=2.13(3)$ $\AA$. The angle for hydrogen bond $\mathrm{N} 1-\mathrm{H} 02$. . O 2 is $161(1)^{\circ}$ and for $\mathrm{N} 1-\mathrm{H} 01 \ldots \mathrm{O} 2$ it is $155(1)^{\circ}$.

\subsubsection{Crystal structure of [Ni(M5FTSC $\left.)_{2}\right]$}

This structure is solved with little data because of the small size of the crystal (Table 1). The bond distances, angles and the geometry of $\mathrm{Ni}(\mathrm{M} 5 \mathrm{FTSC})_{2}$ molecules in the crystal $\left[\mathrm{Ni}(\mathrm{M} 5 \mathrm{FTSC})_{2}\right]$ are similar to those of the $\left[\mathrm{Ni}(\mathrm{M} 5 \mathrm{FTSC})_{2}\right] \cdot 2 \mathrm{DMF}$ crystal, as mentioned above in Table 2 .

The molecular arrangement in the unit-cell, shows that the atoms $\mathrm{Ni}$ and $\mathrm{S}$ are again according to (001) plane, with an interspacing of about 7.30(1) $\AA$. The rest of the atoms of the complex are within the interspace.

\subsection{Spectroscopic study}

As all thiosemicarbazones, our ligand can exhibit thione-thiol tautomerism, since it contains a thioamide $-\mathrm{NH}-\mathrm{C}=\mathrm{S}$ functional group [21]. There is no IR band at $2500-2600 \mathrm{~cm}^{-1}$ in the spectrum of the free ligand, and this indicates the absence of $\mathrm{S}-\mathrm{H}$ grouping in the free ligand. However, there are bands in the regions of 855 and $3150 \mathrm{~cm}^{-1}$, characteristic of $\nu(\mathrm{C}=\mathrm{S})$ and $\nu(\mathrm{N}-\mathrm{H})$, respectively, indicating that the ligand remains as the thione tautomer. This is supported by the ${ }^{1} \mathrm{H}$ NMR spectrum which does not show any peak at $4 \mathrm{ppm}$ attributable to the $\mathrm{S}-\mathrm{H}$ proton, but it shows a singular peak at $11.3 \mathrm{ppm}$ relative to the $\mathrm{NH}$ next to $\mathrm{C}=\mathrm{S}$.

The bands appearing around 1345 and $785 \mathrm{~cm}^{-1}$ in the spectrum of the ligand are either weakened or shifted to higher wave numbers in all the complexes [22,23], and this shift can be assigned to $\nu(\mathrm{C}=\mathrm{S})$ vibration. On the other hand, the bands in the region $3440-3270 \mathrm{~cm}^{-1}$ attributed to symmetrical and asymmetrical stretching mode $\nu\left(\mathrm{NH}_{2}\right)$ in the spectra of the ligand, undergo appreciable change in the spectra of the complexes. This is due to the coordination of sulfur from the $\mathrm{C}=\mathrm{S}\left(\mathrm{NH}_{2}\right)$ group as reported earlier [24]. This coordination is confirmed by the presence of a new band at $380-395 \mathrm{~cm}^{-1}[5,25]$ which is assigned to $\nu(\mathrm{M}-\mathrm{S})$ for all the complexes.

In ligand spectra, the strong band observed at 1600 $\mathrm{cm}^{-1}$ corresponds to $\nu(\mathrm{C}=\mathrm{N})$ vibration band [24]. This band shifts to a higher region [22,24] in the spectra of nickel complexes and this indicates the coordination of nitrogen of the azomethine group to the central metal atoms in these complexes. The presence of a new band in 
$b \stackrel{4}{a}$

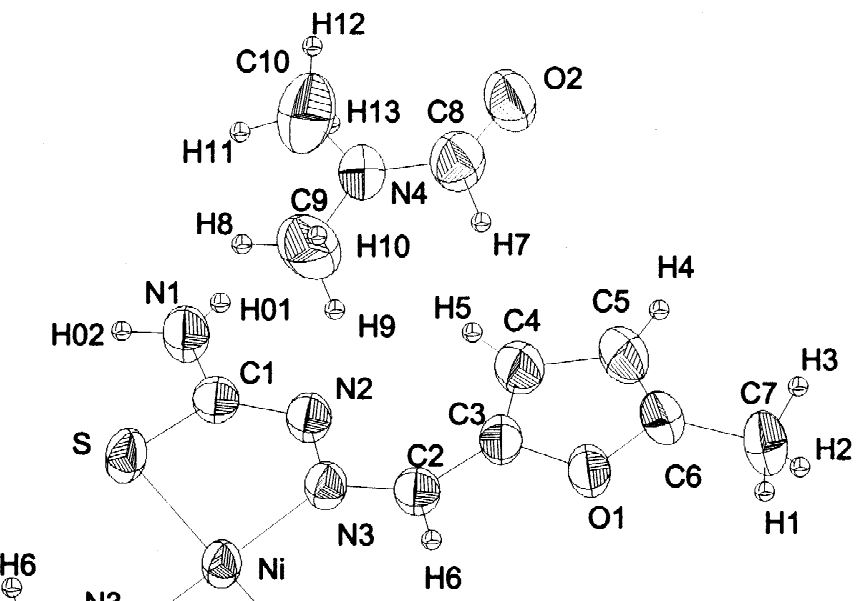

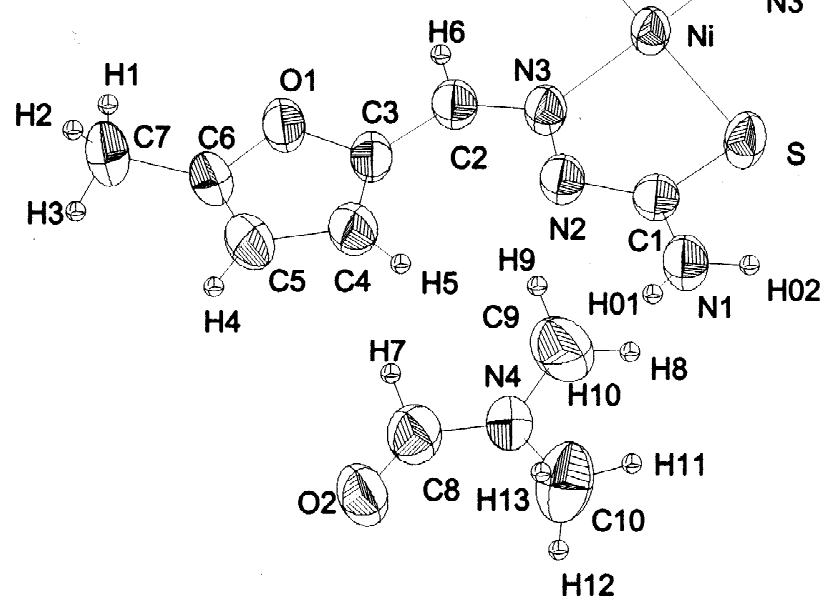

Fig. 1. Perspective view of complex and atom numbering of $\left[\mathrm{Ni}(\mathrm{M} 5 \mathrm{FTSC})_{2}\right] \cdot 2 \mathrm{DMF}$.

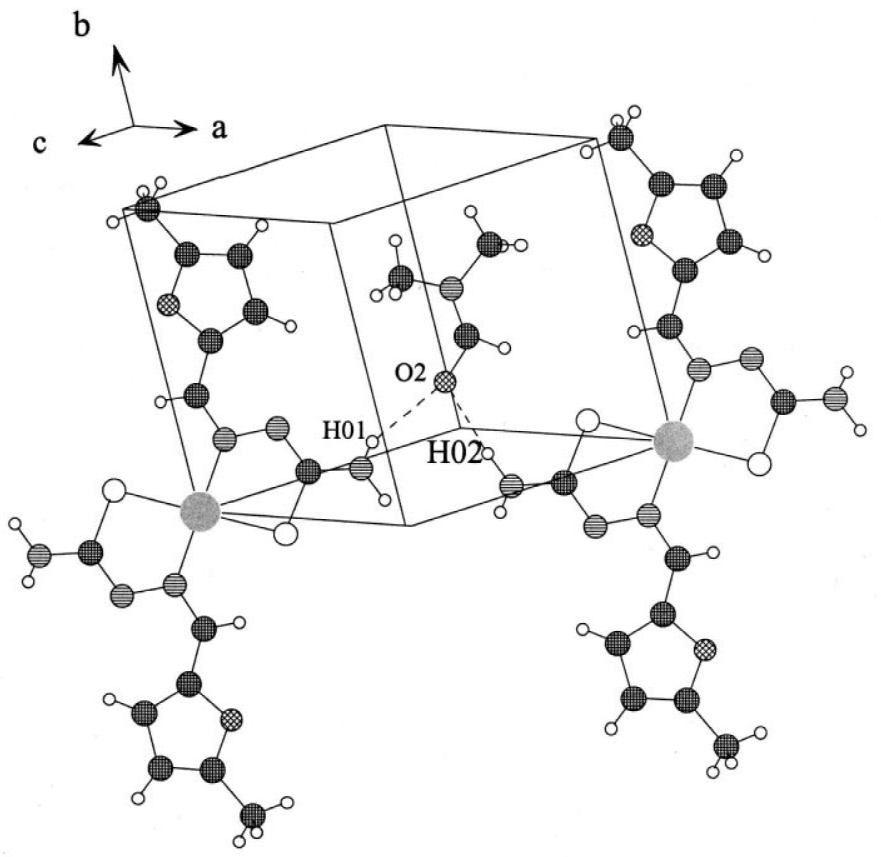

Fig. 2. Hydrogen bonding in $\left[\mathrm{Ni}(\mathrm{M} 5 \mathrm{FTSC})_{2}\right] \cdot 2 \mathrm{DMF} \mathrm{X}$-ray structure. 
the region $440-450 \mathrm{~cm}^{-1}$ due to $\nu(\mathrm{Ni}-\mathrm{N})$ is another indication of the involvement of nitrogen of the azomethine group in coordination [5,25]. In the spectra of $\left[\mathrm{Ni}(\mathrm{M} 5 \mathrm{HFTSC})_{2} \mathrm{Cl}_{2}\right]$ and $\left[\mathrm{Ni}(\mathrm{M} 5 \mathrm{HFTSC})_{2} \mathrm{Br}_{2}\right]$ several bands were observed in the region $220-280 \mathrm{~cm}^{-1}$, corresponding to nickel-chloride and nickel-bromide stretching vibrations [7,10].

On the other hand their electronic spectra show three bands at 8165,13985 and $29678 \mathrm{~cm}^{-1}$ for the chloride complex and at 7875,13160 and $23950 \mathrm{~cm}^{-1}$ for the bromide complex. The use of König's relation [26] lead to relative values of $10 \mathrm{Dq}: 8165 \mathrm{~cm}^{-1}\left(\mathrm{Cl}^{-}\right)$and $7875 \mathrm{~cm}^{-1}$ $\left(\mathrm{Br}^{-}\right)$. There are no significant differences between experimental and calculated values of $\nu_{1}, \nu_{2}$ and $\nu_{3}$. These values are in good agreement with those of trans dihalogeno octahedral structures [27].

\subsection{Biological test}

In a previous study [28], it was found that the ligand furfural thiosemicarbazone was a very active fungicide against phytopathogenic fungi such as Alternaria tenuis and Helminthosporium sativum but the combined activity of the ligand with that of cobalt was lower than expected. In this study, fungitoxicity of $\left[\mathrm{Ni}(\mathrm{M} 5 \mathrm{HFTSC})_{2} \mathrm{Cl}_{2}\right]$ and $\left[\mathrm{Cu}(\mathrm{M} 5 \mathrm{HFTSC}) \mathrm{Cl}_{2}\right]$ complexes has been evaluated against two important human pathogen fungi: the filamentous fungus $A$. fumigatus and the yeast $C$. albicans (Table 3 ). In contrast to the previous study, no antifungal activity for the ligand was found, however, it was observed that after complex formation with nickel and copper, the combined activities were not modified in comparison to the activities of free metals. Eventually, our study of toxicity on mice showed that coordination to nickel and copper did not diminish the toxicity of free metals. Nevertheless, a slight effect of copper complex on the growth of $C$. albicans can be noticed. It may be concluded that complexation of furfural thiosemicarbazone with nickel or copper had no effect on biological activities of the corresponding free metals.
Our results are in agreement with other authors who demonstrated no antifungal activity against Aspergillus niger and Paecilomyces variotii for derived salicylaldehyde thiosemicarbazones with copper(II) [29]. Other studies $[7,30]$ reported that complexes of acetylpyridine ethylthiosemicarbazone with transition metals like iron(III), cobalt(II) and (III), nickel(II), copper(II), zinc(II), cadmium(II) or mercury(II) had little or no activities against previous fungi. Recently, de Souza et al. [31] showed that 2-acetylpyridine 3-hexamethylene-iminylthiosemicarbazone complexes of zinc(II) or tin(IV) have no activity against $A$. niger and only modest activity against $P$. variotii.

\section{Supplementary materials}

Crystallography data have been deposited with the CCDC (12 Union Road, Cambridge, CB2 1EZ, UK) and are available on request quoting the deposition numbers CCDC 152338 and 152339.

\section{References}

[1] Y. Kang, N. Yang, S.O. Kang, J. Ko, C.H. Lee, Y.H. Lee, Organometallics 16 (1997) 5522.

[2] D.X. West, J.K. Swearingen, J. Valdés-Martínez, S. HernándezOrtega, A.K. El-Sawaf, F. van Meurs, A. Castiñeiras, I. Garcia, E. Bermejo, Polyhedron 18 (1999) 2919.

[3] P. Tarasconi, S. Capacchi, G. Pelosi, M. Cornia, R. Albertini, A. Bonati, P.P. Dall'Aglio, P. Lunghi, S. Pinelli, Bioorg. Med. Chem. 8 (2000) 157.

[4] A. Kumar, U. Chandra, S. Chandra, Synth. React. Inorg. Met. Org. Chem. 23 (4) (1993) 671.

[5] L.J. Ackerman, P.E. Fanwick, M.A. Green, E. John, W.E. Running, J.K. Swearingen, J.W. Webb, D.X. West, Polyhedron 18 (1999) 2759.

[6] S.G. Teoh, S.H. Ang, H.K. Fun, C.W. Ong, J. Organomet. Chem. 580 (1999) 17

[7] E. Bermejo, R. Carballo, A. Castiñeiras, R. Dominguez, C. MaichleMössmer, J. Strähle, D.X. West, Polyhedron 18 (1999) 3695.

Table 3

Biological activities of free metals and metal complexes

\begin{tabular}{lccc}
\hline Compounds & $\begin{array}{l}\text { Antifungal activity } \\
\mathrm{MIC}_{80} \text { values }\left(\mu \mathrm{gll}^{-1}\right)^{\mathrm{a}}\end{array}$ & $\begin{array}{r}\text { Toxicity in mice } \\
\mathrm{LD}_{50}\left(\mu \mathrm{gg}^{-1}\right)^{\mathrm{b}}\end{array}$ \\
\cline { 2 - 3 } & A. fumigatus & C. albicans & $\mathrm{ND}$ \\
\hline Amphotericin B & 8 & 1 & $\mathrm{ND}$ \\
$\mathrm{M} 5 \mathrm{FTSC}$ & 125 & $>250$ & 23 \\
$\mathrm{CuCl}_{2} \cdot 2 \mathrm{H}_{2} \mathrm{O}$ & 8 & 250 & 25 \\
{$\left[\mathrm{CuCl}_{2}(\mathrm{M} 5 \mathrm{FTSC})\right]$} & 16 & 32 & $7.4 \times 10^{3}$ \\
$\mathrm{NiCl}_{2} \cdot 6 \mathrm{H}_{2} \mathrm{O}$ & 125 & 16 & 16 \\
{$\left[\mathrm{NiCl}_{2}\right.$ (M5FTSC)] } & 250 & 16 & $10^{4}$ \\
\hline
\end{tabular}

\footnotetext{
${ }^{\mathrm{a}} \mathrm{MIC}_{80}$ : The spectrophotometric MIC (minimum inhibitory concentration) endpoint was calculated from the turbidimetric data as the lowest drug concentration giving rise to an inhibition of growth equal to or greater than $80 \%$ of that of the drug-free control (MIC $80 \%$ ).

${ }^{\mathrm{b}}$ Dose leading to $50 \%$ dead mice 7 days after intraperitoneal injection (lethal dose).

${ }^{\mathrm{c}}$ Positive control. ND, not determined.
} 
[8] S. Abram, C. Maichle-Mössmer, U. Abram, Polyhedron 17 (1998) 131.

[9] G. Bouet, J. Dugué, Transit. Met. Chem. 15 (1990) 257.

[10] G. Ibrahim, M.A. Khan, P. Richomme, O. Benali-Baïtich, G. Bouet, Polyhedron 16 (1997) 3455.

[11] I.H. Hall, K. Taylor, M.C. Miller, X. Do Thanh, M.A. Khan, G. Bouet, Anticancer Res. 17 (1997) 2411.

[12] D.X. West, J. S Ives, J. Krejci, M.M. Salberg, T.L. Zumbahlen, G.A. Bain, A.E. Liberta, J. Valdés-Martínez, S. Hernández-Ortega, R. A Toscano, Polyhedron 14 (1995) 2189.

[13] M.B. Ferrari, G.G. Fava, E. Leporati, G. Pelosi, R. Rossi, P. Tarasconi, R. Albertini, A. Bonati, P. Lunghi, S. Pinelli, J. Inorg. Biochem. 70 (1998) 145.

[14] Q.X. Li, H.A. Tang, Y.Z. Li, M. Wang, L.F. Wang, C.G. Xia, J. Inorg. Biochem. 78 (2000) 167.

[15] M.B. Ferrari, S. Capacchi, G. Reffo, G. Pelosi, P. Tarasconi, R. Albertini, S. Pinelli, P. Lunghi, J. Inorg. Biochem. 81 (2000) 89.

[16] E.M. Jouad, A. Riou, M. Allain, M.A. Khan, G.M. Bouet, Polyhedron 20 (2001) 67.

[17] Molecular Enraf-Nonius (MolEN), Crystal Structure Analysis, Delft Instruments X-ray Diffraction B.V, Rontnenweg 1, 2624 BD Delft, The Netherlands, 1990.

[18] National Committee for Clinical Laboratory Standards, Reference Method for Broth Dilution Antifungal Susceptibility Testing of Yeasts. Approved Standard M27-A, National Committee for Clinical Laboratory Standards, Villanova, PA, 1997.

[19] D.X. West, Y. Yonghong, T.L. Klein, K.I. Goldberg, A.E. Liberta, J. Valdès-Martinez, S. Hernandez-Ortega, Polyhedron 14 (1995) 3051.
[20] D.X. West, G.A. Bain, R.J. Butcher, J.P. Jasinski, L. Yu, R.Y. Pozdniakiv, J. Valdés-Martínez, R.A. Toscano, S. Hernádez-Ortega, Polyhedron 15 (1996) 665.

[21] Y. Tian, C. Duan, C. Zhao, X. You, Inorg. Chem. 36 (1997) 1247.

[22] M. Rodriguez-Argüelles, M.B. Ferrari, G.G. Fava, C. Pelizzi, G. Pelosi, R. Albertini, A. Bonati, P.P. Dall'Aglio, P. Lunghi, S. Pinelli, J. Inorg. Biochem. 66 (1997) 7.

[23] L. Lima, L.R. Teixeira, T.G. Carneiro, H. Beraldo, J. Braz. Chem. Soc. 10 (1999) 184.

[24] P. Bindu, M.R.P. Kurup, T.R. Satyakeerty, Polyhedron 18 (1999) 321.

[25] J. Garcia-Tojal, L. Lezama, J.L. Pizarro, M. Insausti, M.I. Arriortua, T. Rojo, Polyhedron 18 (1999) 3703.

[26] E. König, Struct. Bond. (Berl.) 9 (1971) 175.

[27] A.B.P. Lever, Inorganic Electronic Spectroscopy, 2nd Edition, Elsevier, Amsterdam, 1984, 480 pp.

[28] M.P. Swami, D. Gupta, M. Mohan, A.K. Srivastata, Proc. Nat. Acad. Sci. India 50 (1980) 176.

[29] J. Valdés-Martínez, R.A. Toscano, A. Zentella-Dehesa, M.M. Salberg, G.A. Bain, D.X. West, Polyhedron 15 (1996) 427.

[30] D.X. West, C.S. Carlson, A.C. Whyte, A.E. Liberta, Transit. Met. Chem. 15 (1990) 43.

[31] G.F. de Sousa, D.X. West, C.A. Brown, J.K. Swearingen, J. ValdésMartínez, R.A. Toscano, S. Hernández-Ortega, M. Hörner, A.J. Bortoluzzi, Polyhedron 19 (2000) 841. 